\title{
PEST ANALYSIS SEBAGAI STRATEGI PENINGKATAN PELAYANAN PERGURUAN TINGGI KEAGAMAAN BUDDHA
}

\author{
Heriyanto \\ heriyanto@stabn-sriwijaya.ac.id
}

\begin{abstract}
ABSTRAK
Tujuan penelitian ini adalah mendeskripsikan bagaimana PEST analysis sebagai strategi peningkatan pelayanan Perguruan Tinggi Keagamaan Buddha (PTKB). Fokus penelitian pada analisis faktor eksternal yang mempengaruhi PTKB ditinjau dari politik/hukum, ekonomi, sosial, dan teknologi, yang selanjutnya digunakan dalam menentukan strategi guna peningkatan pelayanan PTKB.
\end{abstract}

Penelitian kualitatif dengan pendekatan eksploratif. Subjek penelitian terdiri dari dosen, mahasiswa, dan para pemegang kebijakan manajemen perguruan tinggi. Objek penelitian meliputi berbagai faktor eksternal organisasi ditinjau dari faktor politik, ekonomi, sosial, dan teknologi. Analisis data menggunakan model miles and huberman. Analisis lingkungan eksternal dengan PEST Analysis dan Value Chain Analysis digunakan untuk menentukan proses utama dan pendukung PTKB. Metode pengumpulan data dengan wawancara, observasi, dan dokumentasi. Data skunder menjadi data penting dalam penelitian untuk mencari faktor eksternal makro PTKB.

Hasil penelitian menunjukan strategi peningkatan pelayanan PTKB melalui pendidikan dan pembelajaran yaitu: (1) restrukturisasi dan manajemen kurikulum, (2) adopsi teknologi informasi dan komunikasi dalam proses pembelajaran, penelitian, dan pengabdian masyarakat, (3) forum dan diskusi ilmiah antarPTKB, (5) program beasiswa dan bantuan pendidikan, (6) kerja sama antarPTKB, (7) pembinaan kerukunan antarumat beragama, penerapan metode, model, strategi, dan pendekatan pembelajaran yang sesuai dengan karakteristik mahasiswa, (8) workshop, pelatihan, bimbingan teknologi informasi dalam pembelajaran (9) peningkatan kualifikasi dosen, dan (10) keterlibatan masyarakat dalam proses pembelajaran. Strategi bidang penelitian dilakukan dengan memberikan kontribusi nyata penelitian dan pengabdian masyarakat berbasis kebutuhan dan pemberdayaan. Bidang pengabdian masyarakat dengan berbagai kegiatan yang lebih menekankan pada dimensi sosial perguruan tinggi sebagai sebuah institusi pendidikan tinggi serta melakukan pelatihan dan bimbingan dengan perkembangan TIK. Strategi bidang pendukung PTKB seperti: (1) pendanaan dengan perencanaan kebutuhan dan berbasis program, (2) update informasi peraturan serta kebijakan pendidikan dan PTKB, (3) peran maksimal kinerja divisi kepegawaian, (4) studi lanjut dosen dan tenaga kependidikan, (5) penerimaan pegawai, (6) koordinasi yang baik PTKB dengan Direktorat Jenderal Bimbingan Masyarakat Buddha, (7) membentuk SDM TI serta divisi manajemen sistem informasi dan pangkalan data, dan (8) peningkatan sarana prasarana, infrastruktur teknologi serta sesosialisasi, promosi, dan publikasi PTKB secara berkelanjutan.

PEST Analysis, Value Chain Analysis, Perguruan Tinggi Keagamaan Buddha 


\section{Pendahuluan}

Pendidikan tinggi merupakan gerbang utama pencetak insan intelektual melalui berbagai proses yang dilakukan. Perkembangan agama tidak terlepas dari peran masyarakat intelektual dengan berbagai kompetensi yang dimiliki. Perguruan Tinggi Keagamaan Buddha (PTKB) menjadi basis utama dalam pendidikan tinggi, penemuan, dan riset baru yang digunakan dalam mendukung pelayanan bidang agama dan keagamaan Buddha. Peran strategis perguruan tinggi (negeri maupun swasta) mencetak Sumber Daya Manusia (SDM) intelektual tidak terlepas dari permasalahan internal maupun eksternal perguruan tinggi. Lingkungan eksternal perguruan tinggi berpengaruh besar terhadap perkembangan, operasional, pelayanan, dan jasa pendidikan yang diberikan.

Perubahan lingkungan perguruan tinggi terjadi melalui pergeseran paradigma, manajemen pengelolaan, dan persaingan pendidikan. Perubahan paradigma pendidikan terjadi akibat globalisasi dan arus perkembangan teknologi informasi. Globalisasi menjadi tantangan dan permasalahan bagi masa depan perguruan tinggi, menjadi pertanyaan utama perguruan tinggi dalam melaksanakan proses pendidikan, penelitian, dan pengabdian kepada masyarakat. Globalisasi harus dipahami dan dianalisis sebagai situasi multidimensi meliputi berbagai bidang kegiatan dan interaksi ekonomi, politik, sosial budaya, teknologi, etik, lingkungan, dan personal.

Dinamika politik/hukum, perekonomian masyarakat, pergeseran dan perubahan sosial, serta kemajuan teknologi memberikan pengaruh terhadap keberlangsungan perguruan tinggi dalam menjalankan tugas dan fungsi. PEST analysis memberikan gambaran situasi dan kondisi lingkungan eksternal ditinjau dari faktor politik/hukum, ekonomi, sosial, dan teknologi. Fakta menampilkan kendala PTKB di Indonesia tidak lepas dari faktor politik (hukum dan perundang-undangan, kebijakan), ekonomi masyarakat, sosial kultural, serta adopsi teknologi yang berkembang dalam dunia pendidikan. Beberapa kendala PTKB seperti: (1) program studi jenjang S2 berstatus tutup pada Pangkalan Data Pendidikan Tinggi dikarenakan tidak dapat memenuhi persyaratan Peraturan Menteri Riset, Teknologi, dan Pendidikan Tinggi Republik Indonesia, (2) penghasilan keluarga dan biaya kuliah berakibat pada menurunnya jumlah mahasiswa, (3) kurangnya penerapan hasil penelitian terhadap pembelajaran dan masyarakat, (4) belum maksimalnya pengabdian berbasis kebutuhan dan pemberdayaan berkelanjutan, (5) lemahnya kepercayaan masyarakat dan daya dukung lingkungan, (6) kurangnya adopsi teknologi dalam meningkatkan proses dan hasil pembelajaran, serta belum maksimalnya manajemen data dan informasi dalam memenuhi berbagai kebutuhan akademik dan pelaporan.

Dengan analisis mendalam data kualitatif perguruan tinggi serta berbagai faktor politik/hukum, ekonomi, sosial, dan teknologi yang mempengaruhi, PEST analysis memberikan gambaran peluang, ancaman, situasi, dan posisi perguruan tinggi saat ini. Analisis menghasilkan arah perencanaan dan langkah-langkah strategis sebagai dasar implementasi untuk keluar dari hambatan yang ada, serta memberikan pelayanan maksimal dalam proses pendidikan. 
Bagaimana PEST Analysis sebagai strategi peningkatan pelayanan PTKB menjadi permasalahan tersendiri dalam penelitian ini. Tujuan penelitian adalah mendeskripsikan bagaimana PEST Analysis sebagai strategi peningkatan pelayanan PTKB. Hasil penelitian memiliki kontribusi untuk beberapa aspek yaitu: aspek teori, sistem, teknis atau praktik, kebijakan dan manajemen, serta aspek penelitian lanjutan.

\section{Landasan Teori}

\section{Pelayanan}

Layanan merupakan kegiatan atau serangkaian yang berlangsung dalam interaksi dengan orang atau mesin fisik dan memberikan kepuasan konsumen. Dalam organisasi, layanan yang diberikan menjadi satu kesatuan dalam sebuah pelayanan untuk memenuhi apa yang dibutuhkan oleh pihak lain. Pelayanan merupakan upaya pemenuhan kebutuhan dan keinginan konsumen serta ketetapan penyampaiannya dalam mengimbangi kebutuhan konsumen (Tjiptono, 2012: 37). Pelayanan juga diartikan sebagai pemenuhan kebutuhan dan tidak harus terkait pada penjualan produk atau pelayanan lain. Pelayanan dapat juga dikatakan sebagai aktifitas manfaat dan kepuasan yang ditawarkan untuk dijual. Pelayanan adalah setiap tindakan atau kegiatan yang dapat ditawarkan oleh suatu pihak kepada pihak lain, yang pada dasarnya tidak berwujud dan tidak mengakibatkan kepemilikan apapun (Kotler, 2012: 356).

Pelayanan merupakan bentuk lain dari jasa yang ditawarkan baik oleh perusahaan, institusi pemerintah maupun swasta. Pelayanan sebagai bentuk jasa, yang merupakan tanggung jawab dan kewajiban bagi institusi terkait. Pelayanan diberikan sebagai daya upaya yang dilakukan berkaitan dengan berbagai produk, jasa, dan layanan yang diberikan. Dari beberapa definisi diatas, pelayanan merupakan berbagai upaya yang dilakukan perusahaan, instansi, intitusi, dan berbagai organisasi guna memberikan nilai lebih kepada pengguna, konsumen, dan penerima atas jasa yang dilakukan. Pelayanan yang baik akan memberikan pandangan dan persepsi baik kepada konsumen dan pengguna jasa. Begitu juga sebaliknya, pelayanan yang buruk akan memberikan kesan negatif dan berdampak terhadap kelangsungan organisasi dimasa depan.

\section{Pelayanan Perguruan Tinggi}

Perguruan tinggi merupakan salah satu institusi yang bergerak dalam bidang jasa pendidikan. Pada institusi pendidikan khususnya perguruan tinggi, pelayanan yang diberikan berkaitan dengan adanya interaksi antara perguruan tinggi dengan mahasiswa dan masyarakat, yang secara baku tertuang dalam Tridarma Perguruan Tinggi. Kualitas pelayanan pada perguruan tinggi, merupakan perbandingan harapan mahasiswa dengan kinerja perguruan tinggi berkaitan dengan pelayanan akademik yang diberikan. Pelayanan yang dirasakan oleh mahasiswa dalam hal ini penerima jasa pendidikan pada akhirnya dapat menentukan tingkat kepuasan (customer satisfaction) mahasiswa. 
Keberadaan perguruan tinggi sangat tergantung pada minat mahasiswa untuk masuk sebagai konsumen dan pengguna jasa pendidikan. Semakin banyaknya perguruan tinggi yang ada, menyebabkan mahasiswa sebagai konsumen dan pengguna jasa semakin diberikan banyak pilihan, pelayanan memberikan nilai tambah terhadap perguruan tinggi yang berakibat pada tingkat kepuasan mahasiswa dan daya kompetitif perguruan tinggi.

Beberapa bidang pelayanan yang dikembangkan secara berkelanjutan pada perguruan tinggi meliputi kurikulum program studi, proses pembelajaran, SDM (dosen dan tenaga kependidikan), sarana dan prasarana, suasana akademik, penelitian dan publikasi ilmiah, pengabdian kepada masyarakat, sistem informasi akademik, kerja sama dalam/luar negeri, dan kontribusi sosial perguruan tinggi terhadap masyarakat. Perhatian terhadap peningkatan kualitas pelayanan dari berbagai proses pendidikan yang dilakukan, menjadi semakin penting untuk terciptanya kepuasan mahasiswa dan keberhasilan perguruan tinggi mencapai tujuan pendidikan yang telah ditetapkan. Dimensi perguruan tinggi dalam bidang sosial masyarakat menjadikan sebuah perguruan tinggi untuk ikut andil memberikan kesejahteraan masyarakat melalui penyelesaian berbagai problema dan permasalahan. Proses dan hasil pendidikan harus mampu menyentuh ranah sosial masyarakat sesuai dengan amanat yang diemban dalam pelaksanaan pendidikan tinggi.

\section{Perguruan Tinggi Keagamaan Buddha}

Pendidikan tinggi adalah pendidikan pada jalur pendidikan sekolah pada jenjang yang lebih tinggi daripada pendidikan menengah di jalur pendidikan sekolah. Sedangkan perguruan tinggi adalah satuan pendidikan yang menyelenggarakan pendidikan tinggi (Indrajit dan Djokopranoto, 2004: 13). Dalam Peraturan Menteri Agama Republik Indonesia Nomor 39 Tahun 2014 Tentang Pendidikan Keagamaan Buddha, Pendidikan Keagamaan Buddha adalah pendidikan yang mempersiapkan peserta didik untuk dapat menjalankan peranan yang menuntut penguasaan pengetahuan tentang ajaran agama Buddha dan/atau menjadi ahli ilmu agama dan mengamalkan ajaran agamanya. Pendidikan keagamaan meliputi pendidikan keagamaan Islam, Kristen, Katolik, Hindu, Buddha, dan Konghucu.

Perguruan Tinggi Kegamaan Buddha Negeri (PTKBN) merupakan perguruan tinggi keagamaan Buddha yang didirikan dan diselenggarakan oleh Pemerintah. Perguruan Tinggi Keagamaan Buddha Swasta (PTKBS) merupakan perguruan tinggi keagamaan Buddha yang didirikan dan diselenggarakan oleh masyarakat. Badan penyelenggara PTKBS adalah badan hukum nirlaba yang dapat berbentuk yayasan/perkumpulan/ perserikatan/paguyuban. PTKB berada dibawah pembinaan Kementerian Agama Republik Indonesia, dan Direktorat Jenderal Bimbingan Masyarakat Buddha (Ditjen Bimas Buddha) sebagai pembina teknis. Pemerintah dalam hal ini Ditjen Bimas Buddha ikut andil dalam kualitas pendidikan tinggi masyarakat Buddha melalui berbagai kebijakan dalam bentuk keputusan, 
peraturan, dan pedoman terhadap pelaksanaan PTKB baik negeri maupun swasta.

4. Strategi

Berkaitan dengan cara dan proses yang dilakukan dalam sebuh organisasi, strategi merupakan sebuah alat (tools) yang digunakan dalam mencapai tujuan yang ditetapkan. Dalam sebuah organisasi, visi dan misi dapat dijadikan sebagai acuan dan arah tujuan berbagai proses dan pelayanan. Strategi adalah sarana bersama dengan tujuan jangka panjang yang hendak dicapai (David, 2011: 18). Strategi merupakan berbagai rencana yang disatukan, menyeluruh, dan terintegrasi melalui cara dan langkah-langkah agar tujuan organisasi dapat tercapai. Strategi tidak hanya berfokus pada tujuan organisasi, tetapi juga dengan memperhatikan faktor internal dan eksternal, serta efektivitas cara dan langkah-langkah dalam proses mencapai tujuan tersebut.

Strategi merupakan rencana berskala besar dengan orientasi masa depan berinteraksi dengan berbagai kondisi persaingan untuk mencapai tujuan perusahaan (Pearce dan Robinson, 2008: 2). Strategi merupakan serangkaian komitmen dan tindakan yang terintegrasi dan terkoordinasi yang dirancang untuk mengeksploitasi kompetensi inti (core competencies) dan mendapatkan keunggulan bersaing (competitive advantage) (Hitt, 2009: 4). Strategi terus berubah, strategi yang tepat dapat membantu organisasi dalam mengalokasikan sumber daya yang dimiliki organisasi berbasis kompetensi internal untuk dapat mengantisipasi berbagai faktor lingkungan yang mempengaruhi. Strategi juga merupakan alat untuk menghadapi berbagai isu strategis dari berbagai bidang dan faktor yang mempengaruhi proses bisnis organisasi.

\section{PEST Analysis}

PEST Analysis merupakan analisis terhadap faktor politik, ekonomi, sosial, dan teknologi. PEST Analysis adalah analisis terhadap faktor lingkungan eksternal yang meliputi bidang politik, ekonomi, sosial, dan teknologi (Ward dan Peppard, 2002: 70). Pada dasarnya PEST Analysis menentukan bagaimana faktor luar seperti politik, ekonomi, sosial, dan teknologi yang mempengaruhi kinerja dan proses bisnis organisasi. PEST Analysis juga sering digunakan bersama dengan alat analisis lain seperti SWOT, Five Forces Porter, dan Value Chain untuk menghasilkan gambaran faktor internal dan eksternal yang mempengaruhi organisasi.

a. Faktor politik pada PEST Analysis meliputi berbagai kebijakan pemerintah, hukum, serta mencakup berbagai aturan formal dan informal dari lingkungan yang dapat mempengaruhi core bisnis organisasi. Isu utama yang menjadi fokus pada faktor politik adalah stabilitas politik, hukum, peraturan, dan perundang-undangan yang berpengaruh terhadap kinerja organisasi. Dalam bidang pendidikan, faktor politik meliputi berbagai kebijakan pemerintah, undang-undang pendidikan, peraturan menteri dan surat keputusan, serta surat edaran berkaitan dengan penyelenggaraan pendidikan. 
b. Kondisi perekonomian dan keuangan negara, tingkat kesejahteraan dan daya beli masyarakat, kebijakan ekonomi, globalisasi ekonomi, pemerataan pembangunan, Sumber Daya Alam (SDA), dan Sumber Daya Manusia (SDM) menjadi faktor eksternal bidang ekonomi yang berpengaruh terhadap lingkungan organisasi. Dalam bidang jasa khususnya pendidikan, faktor ekonomi juga meliputi pertumbuhan ekonomi dan besarnya biaya yang ditawarkan.

c. Faktor sosial dalam lingkungan eksternal terpusat pada penilaian dan sikap konsumen atau pengguna jasa terhadap organisasi itu sendiri. Faktor sosial secara umum meliputi kebudayaan, demografi, pendidikan, tenaga kerja, kesehatan, keluarga, etnis, agama, waktu, dan gender. Faktor-faktor sosial dan budaya memiliki dampak langsung terhadap sikap masyarakat, konsumen, dan perilaku bisnis (Morden, 2007: 99). Tren sosial berpengaruh besar terhadap operasional organisasi, tentunya perencanaan dan strategi peningkatan kinerja organisasi harus mengacu pada perkembangan sosial masyarakat.

d. Strategi dan perencanaan yang baik menjadikan lingkungan sebagai acuan untuk menyesuaikan terhadap perubahan masyarakat. Begitu juga dengan faktor teknologi, teknologi mempengaruhi bahan baku, operasional, produk, dan jasa organisasi. Perubahan teknologi memberikan peluang dan ancaman terhadap hasil produk, pelayanan, dan jasa yang diberikan organisasi. Era informasi mampu mengintegrasikan proses sehingga mempercepat proses internal. Teknologi informasi mampu menggabungkan kehandalan keterampilan fungsional dengan kecepatan proses sehingga memberikan keunggulan kecepatan, efisiensi, dan mutu proses integrasi dalam pelayanan pelanggan (Indrajit dan Djokopranoto, 2004: 120). Pemerintah melalui berbagai kebijakan dan undang-undang menjadi acuan dalam perubahan teknologi. Melakukan inovasi dan mengadopsi teknologi merupakan langkah penting dalam era teknologi informasi dan komunikasi seperti sekarang ini. Fokus pemerintah terhadap pemanfaatan teknologi, penemuan dan pengembangan baru, infrastruktur teknologi, biaya pengadaan dan penggunaan teknologi, serta dampak perubahan teknologi merupakan faktor yang berpengaruh terhadap kapasitas nilai organisasi dalam memberikan suatu produk dan jasa. Teknologi mengacu sebagai sarana yang dipilih untuk memberikan efektivitas suatu proses, mencakup berbagai perkembangan baru yang mengubah pola dan sistem proses, serta perbaikan dalam bahan, design, dan metode (Gufta, 2013: 16).

Fator eksternal dianggap secara bersama-sama mempengaruhi lingkungan bisnis organisasi. Dalam PEST Analysis, faktor lingkungan (environment) dianggap secara bersama-sama menjadi tahapan dalam analisis. Pendekatan juga terjadi pada analisis faktor politik, hukum menjadi faktor yang disertakan dengan faktor politik (Ward dan Peppard, 2002: 70). 


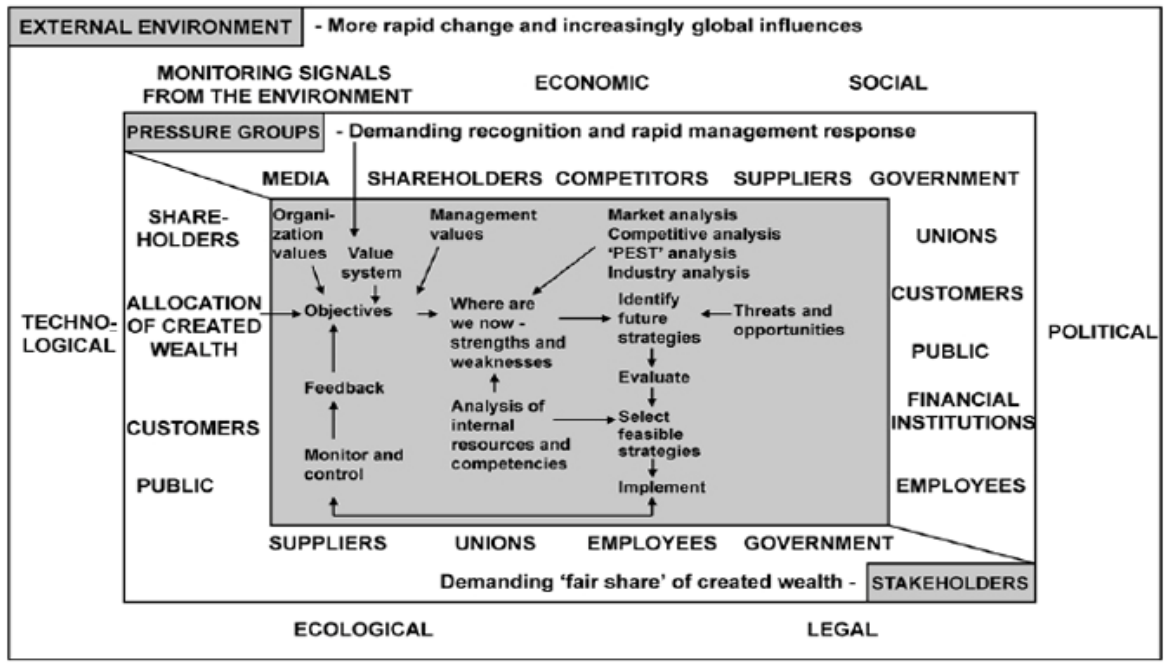

Gambar 1. PEST Framework (Ward and Peppard, 2002: 71)

Faktor sosial berkaitan erat dengan ecology (ekologi) dalam melakukan PEST Analysis, interaksi terhadap lingkungan menjadi faktor berpengaruh dalam menganalisis lingkungan sosial eksternal organisasi.

\section{Metode Penelitian}

Penelitian ini merupakan penelitian kualitatif dengan pendekatan eksploratif. Subjek penelitian terdiri dosen, mahasiswa, serta para pemegang kebijakan dan manajemen perguruan tinggi. Objek penelitian meliputi faktor eksternal organisasi yang mempengaruhi perguruan tinggi ditinjau dari faktor politik, ekonomi, sosial, dan teknologi. Analisis data menggunakan model Miles and Huberman. Analisis lingkungan eksternal dengan PEST Analysis dan Value Chain Analysis (analisis rantai nilai) digunakan untuk menentukan proses utama dan pendukung PTKB. Metode pengumpulan data melalui dokumentasi, observasi, dan wawancara. Data skunder menjadi data penting dalam penelitian untuk mencari faktor eksternal makro PTKB.

Data primer didapatkan langsung melalui dokumentasi, observasi, dan wawancara langsung. Sedangkan data skunder didapatkan dari koran, website, dan berbagai hasil publikasi instansi pemerintah, institusi, organisasi, dan lembaga terkait politik, ekonomi, sosial, dan teknologi. Keabsahan data penelitian dilakukan dengan kredibilitas, transferabilitas, reliabilitas, dan confirmability. Peneliti sebagai instrumen utama dalam penelitian. Wawancara dilakukan menggunakan pedoman wawancara. Observasi dilakukan meliputi actor, activity, place. Sedangkan dokumentasi dilakukan dengan mengumpulkan berbagai pustaka, literatur, dokumen, foto, dan berbagai sumber publikasi yang berkaitan dengan subjek dan objek penelitian. 


\section{Hasil Penelitian dan Pembahasan}

\section{PEST Analysis Perguruan Tinggi Keagamaan Buddha}

Faktor politik/hukum, ekonomi, sosial, dan teknologi eksternal yang mempengaruhi proses bisnis utama PTKB sebagai sebuah institusi pendidikan tinggi tergambar pada tabel 1.

Tabel 1. PEST Analysis Perguruan Tinggi Keagamaan Buddha

\begin{tabular}{|c|}
\hline Politik \\
\hline $\begin{array}{l}\text { a. Reshuffle Kabinet Negara } \\
\text { b. Permenristekdikti dan Peraturan Menteri Agama } \\
\text { (Standar Nasional Pendidikan Tinggi, Pengangkatan dan Pemberhentian } \\
\text { Rektor/Ketua/Direktur pada Perguruan Tinggi Keagamaan Negeri, Pengangkatan dan } \\
\text { Pemberhentian Rektor/Ketua/Direktur pada Perguruan Tinggi Keagamaan yang } \\
\text { diselenggarakan Pemerintah, Registrasi Pendidik pada Perguruan Tinggi) } \\
\text { c. ASEAN Economic Community (AEC) (politik ekonomi dan integrasi ekonomi ASEAN) } \\
\text { d. Direktorat Jenderal Bimbingan Masyarakat Buddha (keputusan, pedoman pelaksanaan, dan } \\
\text { bantuan perguruan tinggi) }\end{array}$ \\
\hline Ekonomi \\
\hline $\begin{array}{l}\text { a. Ekonomi global (integrasi ekonomi dan ketergantungan ekonomi nasional, regional, dan } \\
\text { lokal) } \\
\text { b. Daya beli masyarakat terhadap pendidikan tinggi } \\
\text { c. Penghasilan keluarga }\end{array}$ \\
\hline Sosial \\
\hline $\begin{array}{l}\text { a. Pola pikir peluang dan jaminan kerja } \\
\text { b. Persepsi masyarakat terhadap perguruan tinggi } \\
\text { c. Daya referensi masuk perguruan tinggi } \\
\text { d. Kelompok majelis dan sekte } \\
\text { e. Pola dan trend masyarakat }\end{array}$ \\
\hline Teknologi \\
\hline $\begin{array}{l}\text { a. Basis data perguruan tinggi } \\
\text { b. Paradigma pembelajaran (perkembangan informasi dan komunikasi) } \\
\text { c. Digital Literacy } \\
\text { d. Perkembangan internet, smartphone, media dan jejaring sosial (citizen and netizen) }\end{array}$ \\
\hline
\end{tabular}




\section{Peluang dan Ancaman Perguruan Tinggi Keagamaan Buddha}

Dengan melihat berbagai faktor eksternal PTKB, dapat ditampilkan variabel peluang dan ancaman (opportunities and threats) yang ada dalam menjalankan proses bisnis utama, pelayanan, dan jasa yang diberikan. Peluang dan ancaman terlihat pada tabel 2.

Tabel 2. Peluang dan Ancaman Perguruan Tinggi Keagamaan Buddha

\begin{tabular}{|c|c|c|}
\hline Fenomena Politik & Peluang & Ancaman/hambatan \\
\hline Reshuffle Kabinet Negara & Kebijakan baru yang mendukung PTKB & $\begin{array}{l}\text { Kebijakan bidang pendidikan/pendidikan tinggi } \\
\text { yang berubah-ubah }\end{array}$ \\
\hline Permenristekdikti dan Peraturan Menteri Agama & $\begin{array}{l}\text { a. Standarisasi nasional } \\
\text { b. Kontribusi signifikan } \\
\text { c. Legalitas dosen }\end{array}$ & $\begin{array}{l}\text { a. Proses penyesuaian/standar kualifikasi dosen } \\
\text { b. Persyaratan ketua Perguruan Tinggi Negeri } \\
\text { (SDM yang memenuhi syarat) } \\
\text { c. Persyaratan jumlah minimum dosen program } \\
\text { studi }\end{array}$ \\
\hline $\begin{array}{l}\text { ASEAN Economic Community (AEC) (Ekonomi } \\
\text { politik dan integrasi ekonomi) }\end{array}$ & Kerja sama negara-negara ASEAN & $\begin{array}{l}\text { a. Kebijakan baru bidang pendidikan } \\
\text { b. Daya saing SDM }\end{array}$ \\
\hline $\begin{array}{l}\text { Direktorat Bimbingan Masyarakat Buddha } \\
\text { (kebijakan, pedoman pelaksanaan, dan bantuan } \\
\text { perguruan tinggi) }\end{array}$ & $\begin{array}{l}\text { a. Dukungan kebijakan } \\
\text { b. Bantuan pada perguruan tinggi negeri dan } \\
\text { swasta }\end{array}$ & \\
\hline Fenomena Ekonomi & Peluang & Ancaman/hambatan \\
\hline Ekonomi global & $\begin{array}{ll}\text { a. Lapangan kerja } \\
\text { b. Tenaga kerja } \\
\text { c. Kerja sama } \\
\text { d. Mobilitas barang dan jasa }\end{array}$ & $\begin{array}{l}\text { a. Persaingan global } \\
\text { b. Daya saing lulusan PTKB } \\
\text { c. Kompetensi global } \\
\text { d. Relevansi lulusan terhadap kebutuhan }\end{array}$ \\
\hline Daya beli masyarakat terhadap pendidikan tinggi & Minat terhadap pendidikan meningkat & $\begin{array}{ll}\text { a. } & \text { Daya beli masyarakat terhadap PTKB rendah } \\
\text { b. } & \text { Perguruan Tinggi Umum (PTU) lebih diminati }\end{array}$ \\
\hline Penghasilan keluarga & & Tidak mampu memenuhi biaya kuliah \\
\hline Fenomena Sosial & Peluang & Ancaman/hambatan \\
\hline Pola pikir peluang dan jaminan kerja & & $\begin{array}{ll}\text { a. } & \text { Menurunnya minat pada PTKB } \\
\text { b. } & \text { Pola pikir peluang kerja lulusan PTKB }\end{array}$ \\
\hline
\end{tabular}




\begin{tabular}{|c|c|c|}
\hline Persepsi terhadap perguruan tinggi & Persepsi baik terhadap PTKB tertentu & Persepsi buruk terhadap PTKB tertentu \\
\hline Daya referensi & Dukungan keluarga dan kerabat & $\begin{array}{l}\text { Dukungan rendah untuk menempuh pendidikan } \\
\text { pada PTKB }\end{array}$ \\
\hline Kelompok majelis dan sekte & $\begin{array}{ll}\text { a. } & \text { Kekeluargaan } \\
\text { b. } & \text { Kebersamaan } \\
\text { c. } & \text { Jaringan kerja lulusan PTKB }\end{array}$ & $\begin{array}{l}\text { a. Manajemen eksklusif } \\
\text { b. Mekanisme pasar tidak sempurna } \\
\text { c. Struktur sosial tertutup }\end{array}$ \\
\hline Pola dan tren perkembangan masyarakat & Pergerakan dinamis kebutuhan masyarakat & $\begin{array}{l}\text { a. Adaptasi perguruan tinggi } \\
\text { b. Kontribusi perguruan tinggi } \\
\text { c. Nilai-nilai agama era modern }\end{array}$ \\
\hline Fenomena Teknologi & Peluang & Ancaman/hambatan \\
\hline Basis data perguruan tinggi & $\begin{array}{l}\text { a. Akses informasi } \\
\text { b. Manajemen pelaporan } \\
\text { c. Sentralisasi data akademik } \\
\text { d. Integrasi data dan informasi }\end{array}$ & $\begin{array}{l}\text { a. Infrastruktur sistem dan teknologi } \\
\text { b. SDM yang kompeten } \\
\text { c. Biaya dan pendanaan }\end{array}$ \\
\hline $\begin{array}{l}\text { Paradigma pembelajaran (perkembangan informasi } \\
\text { dan komunikasi) }\end{array}$ & Kebutuhan masyarakat modern & $\begin{array}{l}\text { Kesesuaian metode, model, strategi, dan } \\
\text { pendekatan pembelajaran }\end{array}$ \\
\hline Digital Literacy & $\begin{array}{l}\text { a. Akses terhadap sumber Informasi } \\
\text { b. Layanan berbasis internet } \\
\text { c. Akses informasi berbagai kegiatan akademik }\end{array}$ & $\begin{array}{l}\text { a. SDM bidang digital literacy } \\
\text { b. Dukungan kurikulum } \\
\text { c. Sosialisasi pemanfaatan teknologi dalam } \\
\text { pembelajaran }\end{array}$ \\
\hline $\begin{array}{l}\text { Perkembangan teknologi internet, smartphone, } \\
\text { media dan jejaring sosial (citizen and netizen) }\end{array}$ & $\begin{array}{l}\text { a. Akses internet } \\
\text { b. Akses informasi } \\
\text { c. Kolaborasi, interaksi, diskusi, dan sharing }\end{array}$ & $\begin{array}{l}\text { a. Konten negatif } \\
\text { b. Kemampuan filter dan sharing informasi }\end{array}$ \\
\hline
\end{tabular}




\section{Strategi Perguruan Tinggi Keagamaan Buddha}

PEST Analysis faktor politik, ekonomi, sosial, dan teknologi eksternal menampilkan peluang dan ancaman yang mempengaruhi PTKB sebagai sebuah institusi pendidikan tinggi. Data kualitatif, peluang, dan ancaman perguruan tinggi digunakan untuk merumuskan strategi dalam mengatasi permasalahan yang ada dan memberikan peningkatan terhadap pelayanan PTKB. Strategi PTKB terlihat pada tabel 3.

Tabel 3. Strategi Perguruan Tinggi Keagamaan Buddha

\begin{tabular}{|l|l|l|}
\hline \multicolumn{1}{|c|}{ Peluang } & \multicolumn{1}{|c|}{ Ancaman/hambatan } & \multicolumn{1}{|c|}{ Strategi } \\
\hline Kebijakan baru yang mendukung PTKB & $\begin{array}{l}\text { Kebijakan bidang pendidikan/pendidikan tinggi } \\
\text { yang berubah-ubah }\end{array}$ & $\begin{array}{l}\text { a. Update informasi peraturan dan kebijakan berkaitan } \\
\text { dengan pendidikan dan PTKB } \\
\text { b. Kinerja maksimal divisi kepegawaian PTKB }\end{array}$ \\
\hline $\begin{array}{l}\text { a. Standarisasi nasional } \\
\text { b. Kontribusi signifikan } \\
\text { c. Legalitas dosen }\end{array}$ & $\begin{array}{l}\text { a. Proses penyesuaian/standar kualifikasi dosen } \\
\text { b. Persyaratan ketua Perguruan Tinggi Negeri } \\
\text { (SDM yang memenuhi syarat) } \\
\text { c. Persyaratan jumlah minimum dosen program } \\
\text { studi }\end{array}$ & $\begin{array}{l}\text { a. Peningkatan kualifikasi dosen } \\
\text { b. Studi lanjut } \\
\text { Penerimaan pegawai }\end{array}$ \\
\hline $\begin{array}{l}\text { Kerja sama negara-negara ASEAN } \\
\text { a. Kebijakan baru bidang pendidikan } \\
\text { Daya saing SDM }\end{array}$ & $\begin{array}{l}\text { a. Relevansi kurikulum } \\
\text { bdopsi teknologi informasi dan komunikasi dalam } \\
\text { proses pembelajaran, penelitian, dan pengabdian } \\
\text { masyarakat }\end{array}$ \\
\hline $\begin{array}{l}\text { a. Dukungan kebijakan } \\
\text { b. Bantuan pada perguruan tinggi } \\
\text { swasta dan negeri }\end{array}$ & \multicolumn{2}{|c|}{$\begin{array}{l}\text { Koordinasi PTKB dengan Direktorat Jenderal Bimbingan } \\
\text { Masyarakat Buddha }\end{array}$} \\
\hline
\end{tabular}




\begin{tabular}{|c|c|c|}
\hline Peluang & Ancaman/hambatan & Strategi \\
\hline $\begin{array}{ll}\text { a. Lapangan kerja } \\
\text { b. Tenaga kerja } \\
\text { c. Kerja sama } \\
\text { d. Mobilitas barang dan jasa }\end{array}$ & $\begin{array}{l}\text { a. Persaingan global } \\
\text { b. Daya saing lulusan PTKB } \\
\text { c. Kompetensi global } \\
\text { d. Relevansi lulusan terhadap kebutuhan }\end{array}$ & $\begin{array}{l}\text { Penyesuaian kurikulum, profil lulusan, dan capaian } \\
\text { pembelajaran }\end{array}$ \\
\hline \multirow[t]{2}{*}{ Minat terhadap pendidikan meningkat } & $\begin{array}{l}\text { a. Daya beli masyarakat terhadap PTKB rendah } \\
\text { b. Perguruan Tinggi Umum (PTU) lebih diminati }\end{array}$ & $\begin{array}{l}\text { a. Kontribusi nyata penelitian ilmiah } \\
\text { b. Pengabdian masyarakat berbasis kebutuhan dan } \\
\text { pemberdayaan } \\
\text { c. Sosialisasi, promosi, dan publikasi PTKB }\end{array}$ \\
\hline & Tidak mampu memenuhi biaya kuliah & Program beasiswa dan bantuan pendidikan \\
\hline \multirow[t]{2}{*}{ Peluang } & Ancaman/hambatan & Strategi \\
\hline & $\begin{array}{l}\text { a. Menurunnya minat menempuh pendidikan } \\
\text { pada PTKB } \\
\text { b. Pola pikir peluang kerja lulusan PTKB }\end{array}$ & Kegiatan nyata dimensi sosial perguruan tinggi \\
\hline Persepsi baik terhadap PTKB tertentu & Persepsi buruk terhadap PTKB tertentu & Sosialisasi, promosi, dan publikasi \\
\hline Dukungan keluarga dan kerabat & $\begin{array}{l}\text { Kurang mendukung untuk menempuh pendidikan } \\
\text { pada PTKB }\end{array}$ & Sosialisasi dan promosi PTKB \\
\hline $\begin{array}{l}\text { a. Kekeluargaan } \\
\text { b. Kebersamaan } \\
\text { c. Jaringan kerja lulusan PTKB }\end{array}$ & $\begin{array}{l}\text { a. Manajemen eksklusif } \\
\text { b. Mekanisme pasar tidak sempurna } \\
\text { c. Struktur sosial tertutup }\end{array}$ & $\begin{array}{l}\text { a. Kerja sama antar PTKB } \\
\text { b. Pembinaan kerukunan antar umat beragama } \\
\text { c. Forum dan diskusi ilmiah antar PTKB }\end{array}$ \\
\hline $\begin{array}{l}\text { Pergerakan dinamis kebutuhan } \\
\text { masyarakat }\end{array}$ & $\begin{array}{l}\text { a. Adaptasi perguruan tinggi } \\
\text { b. Kontribusi perguruan tinggi } \\
\text { c. Nilai-nilai agama era modern }\end{array}$ & $\begin{array}{l}\text { a. Relevansi kurikulum dan pembelajaran } \\
\text { b. Pengabdian masyarakat } \\
\text { c. Keterlibatan masyarakat dalam proses pembelajaran }\end{array}$ \\
\hline
\end{tabular}




\begin{tabular}{|l|l|l|}
\hline \multicolumn{1}{|c|}{ Peluang } & \multicolumn{1}{|c|}{ Ancaman/hambatan } & \multicolumn{1}{|c|}{ Strategi } \\
\hline $\begin{array}{l}\text { a. Akses informasi } \\
\text { b. Manajemen pelaporan } \\
\begin{array}{l}\text { c. Sentralisasi data akademik } \\
\text { d. Integrasi data dan informasi }\end{array}\end{array}$ & $\begin{array}{l}\text { a. Infrastruktur sistem dan teknologi } \\
\text { b. SDM yang kompeten } \\
\text { c. Biaya dan pendanaan }\end{array}$ & $\begin{array}{l}\text { a. Divisi manajemen sistem informasi dan pangkalan data } \\
\text { b. SDM IT (Information Technology) } \\
\text { c. Pendanaan } \\
\text { d. Perencanaan sesuai kebutuhan berbasis program }\end{array}$ \\
\hline $\begin{array}{l}\text { Menjawab kebutuhan masyarakat } \\
\text { modern }\end{array}$ & $\begin{array}{l}\text { Metode, model, strategi, dan pendekatan } \\
\text { pembelajaran }\end{array}$ & $\begin{array}{l}\text { Menerapkan metode, model, strategi, dan pendekatan } \\
\text { pembelajaran yang sesuai }\end{array}$ \\
\hline $\begin{array}{l}\text { a. Akses terhadap sumber Informasi } \\
\text { b. Layanan berbasis internet } \\
\text { c. Akses informasi berbagai kegiatan } \\
\text { akademik }\end{array}$ & $\begin{array}{l}\text { a. SDM bidang digital literacy } \\
\text { b. Sukungan kurikulum } \\
\text { pembelajaran }\end{array}$ & $\begin{array}{l}\text { a. SDM Teknologi Informasi (TI) } \\
\text { b. Relevansi kurikulum } \\
\text { c. Workshop, pelatihan, bimbingan teknologi informasi } \\
\text { dalam pembelajaran }\end{array}$ \\
\hline $\begin{array}{l}\text { a. Akses internet } \\
\text { b. Akses informasi } \\
\text { c. Kolaborasi, interaksi, diskusi, dan } \\
\text { sharing }\end{array}$ & $\begin{array}{l}\text { a. Konten negatif } \\
\text { b. Kemampuan filter dan sharing informasi }\end{array}$ & $\begin{array}{l}\text { a. Mata kuliah dan pembelajaran Teknologi Informasi dan } \\
\text { Komunikasi (TIK) } \\
\text { Pelatihan, bimbingan, pengabdian dosen berkaitan } \\
\text { dengan perkembangan TIK }\end{array}$ \\
\hline
\end{tabular}


4. Value Chain Perguruan Tinggi Keagamaan Buddha

Faktor eksternal peluang dan ancaman/hambatan PTKB digunakan untuk merumuskan strategi yang tepat guna memberikan pelayanan maksimal. Strategi yang dihasilkan harus sesuai dengan proses bisnis utama pada perguruan tinggi, khususnya PTKB. Value Chain digunakan untuk memberikan kerangka identifikasi proses utama dan pendukung dalam sebuah organisasi. Analisis Value Chain menampilkan proses utama dan pendukung PTKB untuk menciptakan kesesuaian strategi yang dirumuskan dengan operasional yang dilakukan.

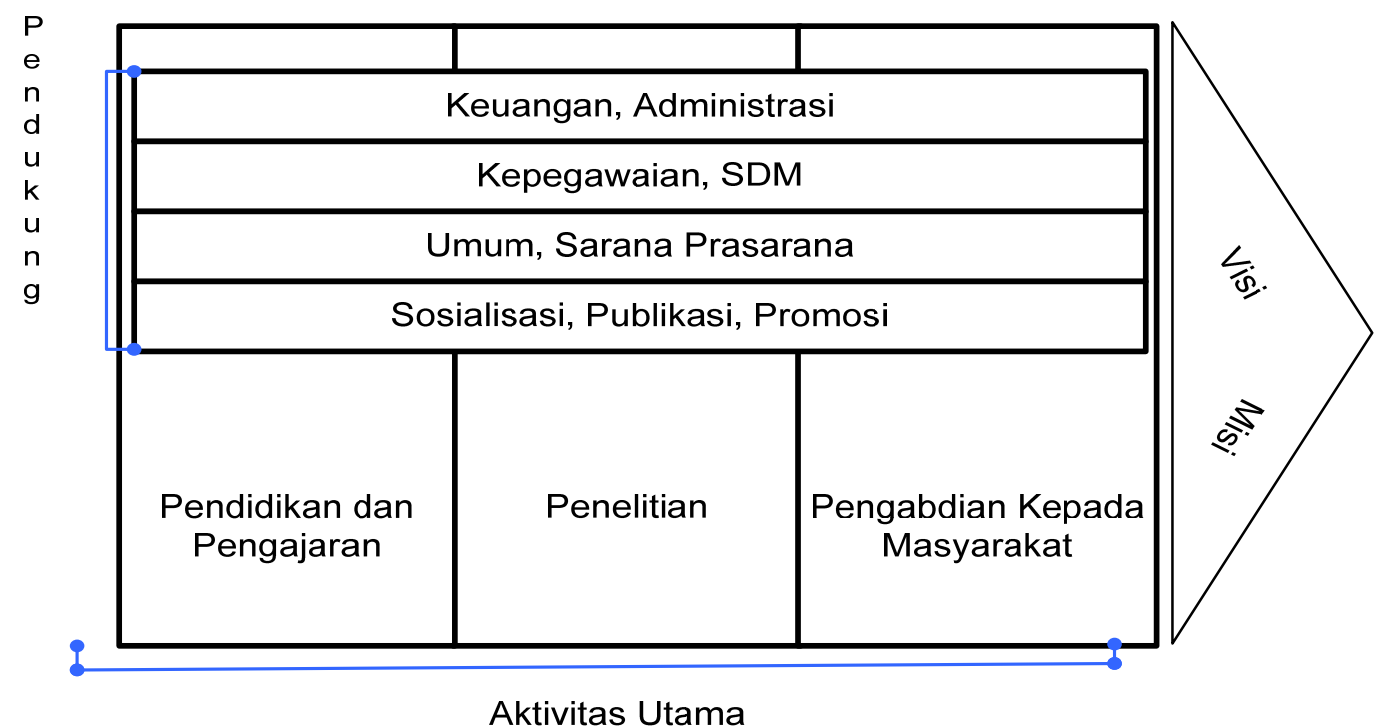

Gambar 1. Value Chain Perguruan Tinggi Keagamaan Buddha

Proses utama sebuah perguruan tinggi merupakan Tridharma Perguruan Tinggi yang meliputi pendidikan dan pengajaran, penelitian, dan pengabdian kepada masyarakat. Proses pendukung pada perguruan tinggi adalah keuangan dan administrasi, kepegawaian dan SDM, umum dan sarana prasarana, serta promosi dan publikasi. Strategi yang dirumuskan harus sesuai dengan proses bisnis utama dan pendukung PTKB sehingga memberikan manfaat yang besar untuk mengatasi berbagai permasalahan dan memberikan pelayanan maksimal.

5. Strategi terhadap Proses Bisnis Perguruan Tinggi Keagamaan Buddha

Strategi merupakan roadmap dan perencanaan yang harus terimplementasi secara nyata melalui berbagai proses yang dilakukan, baik proses utama maupun pendukung pada sebuah PTKB. Penempatan strategi terhadap proses bisnis PTKB terlihat pada tabel 4. 
Tabel 4. Penempatan Strategi terhadap Proses Bisnis PTKB

\begin{tabular}{|c|}
\hline Pendidikan dan Pembelajaran \\
\hline $\begin{array}{l}\text { (1) Restrukturisasi dan manajemen kurikulum, (2) adopsi teknologi informasi dan komunikasi } \\
\text { dalam proses pembelajaran, penelitian, dan pengabdian masyarakat, (3) forum dan diskusi } \\
\text { ilmiah antar-PTKB, (4) program beasiswa dan bantuan pendidikan, (5) kerja sama antar-PTKB, } \\
\text { (6) pembinaan kerukunan antarumat beragama, (7) penerapan metode, model, strategi, dan } \\
\text { pendekatan pembelajaran yang sesuai dengan karakteristik mahasiswa, (8) workshop, pelatihan, } \\
\text { bimbingan teknologi informasi dalam pembelajaran, (9) peningkatan kualifikasi dosen, dan (10) } \\
\text { keterlibatan masyarakat dalam proses pembelajaran. }\end{array}$ \\
\hline Penelitian \\
\hline $\begin{array}{l}\text { Strategi dalam bidang penelitian dilakukan dengan memberikan kontribusi nyata penelitian } \\
\text { ilmiah dan pengabdian masyarakat berbasis kebutuhan dan pemberdayaan. }\end{array}$ \\
\hline Pengabdian kepada Masyarakat \\
\hline $\begin{array}{l}\text { Strategi bidang pengabdian masyarakat terdiri dari berbagai kegiatan berkaitan dimensi sosial } \\
\text { perguruan tinggi. Pelatihan, bimbingan, dan pengabdian dosen berkaitan dengan perkembangan } \\
\text { Teknologi Informasi dan Komunikasi. }\end{array}$ \\
\hline Keuangan dan Administrasi \\
\hline Pendanaan melalui perencanaan sesuai kebutuhan dan berbasis program. \\
\hline Kepegawaian dan SDM \\
\hline $\begin{array}{l}\text { (1) Update informasi berbagai peraturan dan kebijakan berkaitan dengan pendidikan dan PTKB, } \\
\text { (2) peran maksimal kinerja divisi/bagian kepegawaian PTKB dalam tugas dan fungsi, (3) studi } \\
\text { lanjut dosen dan tenaga kependidikan, (4) penerimaan pegawai, (5) koordinasi yang baik PTKB } \\
\text { dengan Direktorat Jenderal Bimbingan Masyarakat Buddha, (6) membentuk SDM Teknologi } \\
\text { Informasi (TI) dan divisi manajemen sistem informasi dan pangkalan data. }\end{array}$ \\
\hline Umum dan Sarana Prasarana \\
\hline Fasilitas dan infrastruktur sistem dan teknologi informasi. \\
\hline Sosialisasi, Promosi, dan Publikasi \\
\hline $\begin{array}{l}\text { Berbagai bentuk sosialisasi, promosi, dan publikasi secara berkelanjutan dalam berbagai bidang } \\
\text { kebutuhan. }\end{array}$ \\
\hline
\end{tabular}

\section{Kesimpulan}

PEST Analysis PTKB terdiri dari faktor politik Reshuffle Kabinet Negara, Permenristekdikti dan Peraturan Menteri Agama, ASEAN Economic Community (AEC) (politik ekonomi dan integrasi ekonomi ASEAN), dan Direktorat Jenderal Bimbingan Masyarakat Buddha (keputusan, pedoman pelaksanaan, dan bantuan perguruan tinggi). Faktor ekonomi terdiri dari ekonomi global, daya beli masyarakat terhadap pendidikan tinggi, dan penghasilan keluarga. Faktor sosial meliputi pola pikir peluang dan jaminan kerja, persepsi masyarakat terhadap perguruan tinggi, daya referensi masuk perguruan tinggi, kelompok majelis dan sekte, serta pola dan tren masyarakat. Faktor teknologi meliputi basis data perguruan tinggi, paradigma pembelajaran (perkembangan informasi dan komunikasi), digital literacy, serta perkembangan teknologi smartphone, media, dan jejaring sosial (citizen and netizen). 
Strategi yang dihasilkan melalui PEST Analysis PTKB, yaitu: (1) restrukturisasi dan manajemen kurikulum, (2) adopsi teknologi informasi dan komunikasi dalam proses pembelajaran, penelitian, dan pengabdian masyarakat, (3) forum dan diskusi ilmiah antar-PTKB, ( 5) program beasiswa dan bantuan pendidikan, (6) kerja sama antar-PTKB, (7) pembinaan kerukunan antarumat beragama, penerapan metode, model, strategi, dan pendekatan pembelajaran yang sesuai dengan karakteristik mahasiswa, (8) workshop, pelatihan, bimbingan teknologi informasi dalam pembelajaran (9) peningkatan kualifikasi dosen, dan (10) keterlibatan masyarakat dalam proses pembelajaran.

Strategi dalam bidang penelitian dilakukan dengan memberikan kontribusi nyata penelitian ilmiah dan pengabdian masyarakat berbasis kebutuhan dan pemberdayaan. Strategi bidang pengabdian masyarakat terdiri dari pengabdian yang lebih menekankan kepada dimensi sosial perguruan tinggi sebagai sebuah institusi pendidikan tinggi serta melakukan pelatihan dan bimbingan dengan perkembangan TIK.

Strategi bidang pendukung PTKB seperti: (1) pendanaan melalui perencanaan sesuai kebutuhan dan berbasis program, (2) update informasi berbagai peraturan dan kebijakan berkaitan dengan pendidikan dan PTKB, (3) peran maksimal kinerja divisi/bagian kepegawaian PTKB dalam tugas dan fungsi, (4) studi lanjut dosen dan tenaga kependidikan, (5) penerimaan pegawai, (6) koordinasi yang baik PTKB dengan Direktorat Jenderal Bimbingan Masyarakat Buddha, (7) membentuk SDM teknologi informasi serta divisi manajemen sistem informasi dan pangkalan data. Strategi proses pendukung PTKB juga dilakukan melalui peningkatan sarana prasaran infrastruktur teknologi, serta sosialisasi, promosi, dan publikasi PTKB secara berkelanjutan.

\section{Referensi}

Abdullah, Mohammad Nayeem dan Robaka Shamsher. "A Study on the Impact of PEST Analysis on the Pharmaceutical Sector: The Bangladesh Context". David Publishing Journal of Modern Accounting and Auditing, ISSN. 15486583, Vol. 7, No. 12, 1446-1456, 2011. Print

AECCenter Kementerian Perdagangan Republik Indonesia. Tentang AEC 2015. 2015. Web. http://aeccenter.kemendag.go.id/tentangaec2015

Badan Pusat Statistik. Indikator Ekonomi, Buletin Statistik Bulanan, Edisi Juli 2016. Print.

Begg dan Connolly. Database Systems A Practical Approach to Design, Implementation, and Management. England: Pearson Education Limited, 2015. Print.

David, F.R. Strategic Management Manajemen Strategi Konsep, Edisi 12. Jakarta: Salemba Empat, 2011. Print.

Direktorat Jenderal Bimbingan Masyarakat Buddha Kementerian Agama Republik Indonesia. Pedoman Pelaksanaan Penetapan Jabatan Fungsional 
Bagi Dosen Bukan Pegawai Negeri Sipil Perguruan Tinggi Keagamaan Buddha, 2015. Print.

Ganesh, R. dan Haslinda, A. Evolution and Conceptual Development of Service Quality in Service Marketing and Customer Satisfaction. International Review of Management and Business Researc. Vol. 3, Issue. 2, Juni 2014. Web. <http://www.irmbrjournal.com>

Gupta, Abhishek. Environmental and PEST Analysis: An Approach to External Business Environment. Merit Research Journal of Art, Social Science and Humanities. Vol. 1(2) pp. 013 017, 2013. Web. 20 Agustus 2016. <http://www.meritresearchjournals.org/assh/index.htm>.

Halimatus. Jokowo Ungkap Alasan Reshuffle Kabinet Kerja. Republika Online. 2016. Web. 29 Juli 2016.

$<$ http://nasional.republika.co.id/berita/nasional/politik/16/07/27/oaymid282j okowiungkapalasanreshufflekabinetkerja $>$.

Hattersley, Millett dan Shop. Computing Fundamentals Digital Literacy Edition. United Kingdom: John Wiley \& Sons, 2014. Print.

Hitt, Ireland, dan Hoskisson. Strategic Management: Competitiveness and Globalization (Concepts and Cases) 8th Edition. USA: South-Western, a part of Cengage Learning, 2009. Print.

Indrajit dan Djokopranoto. Manajemen Perguruan Tinggi Moderen. n.p. n.d. Print.

Kotler, Keller. Manajemen Pemasaran. Yogyakarta: Graha Ilmu, 2009. Print.

Kotler, Keller. Marketing Management 14th. Prentice Hall, New York, 2012. Print.

Koumparouli dan Dimitrios Nikolaou. PEST Analysis: The case of E-Shop. TI Journal: International Journal of Economy, Management and Social Sciences, ISSN. 2306-7276, 2013. Print.

Maturbongs, Yoseph Hendrik dan Riri Satria. Perencanaan Strategis Sistem Informasi pada Institusi Pendidikan Tinggi: Studi Kasus Sekolah Tinggi Ilmu Komunikasi dan Sekretari Tarakanita. Yogyakarta : Seminar Nasional Aplikasi Teknologi Informasi, 17-18 Juni 2011. ISSN: 1907-5022.

Morden, Tony. Principles of Strategic Management, Third Edition. England: Ashgate Publishing Limited, 2007.

Kementerian Agama Republik Indonesia. Keputusan Direktorat Jenderal Bimbingan Masyarakat Buddha No. 436 tahun 2015 Tentang Rencana Strategis Direktorat Jenderal Bimbingan Masyarakat Buddha Tahun 2015 2019.

Kementerian Perdagangan Republik Indonesia. Masyarakat Ekonomi ASEAN 2015: Meningkatkan Daya Saing, Meraih Peluang. Disampaikan Direktur 
Kerjasama ASEAN, Ditjen Kerjasama Perdagangan Internasional, KEMENDAG, 2015. Print.

Pangkalan Data Pendidikan Tinggi (PDDIKTI). Kementerian Riset, Teknologi, dan Pendidikan Tinggi, 2016. Web. http://forlap.dikti.go.id/prodi/detail/OUFFNDM2NUUtODFFRS 00N0MwLUE1RUEtNzE4QzFFODAzRkEz (diakses 12 September 2016).

Peraturan Pemerintah No.37 Tahun 2009, Tentang Dosen. Print.

Peraturan Menteri Agama Republik Indonesia No. 39 Tahun 2014, Tentang Pendidikan Keagamaan Buddha. Print.

Peraturan Menteri Agama Republik Indonesia No. 3 Tahun 2015, Tentang Pengangkatan Dosen Tetap Bukan Pegawai Negeri Sipil Perguruan Tinggi Keagamaan Negeri dan Dosen Tetap Perguruan Tinggi Keagamaan Swasta. Print.

Peraturan Menteri Agama Republik Indonesia No. 1 Tahun 2016, Tentang Perubahan Atas Peraturan Menteri Agama No. 11 Tahun 2014 Tentang Pengangkatan dan Pemberhentian Rektor dan Ketua Pada Perguruan Tinggi Keagamaan yang Diselenggarakan oleh Pemerintah. Print.

Peraturan Menteri Riset, Teknologi, dan Pendidikan Tinggi Republik Indonesai No 44 Tahun 2015, Tentang Standar Nasional Pendidikan Tinggi. Print.

Peraturan Menteri Riset, Teknologi, dan Pendidikan Tinggi Republik Indonesai No 2 Tahun 2016, Tentang Registrasi Pendidik pada Perguruan Tinggi. Print.

Pearce dan Robinson. Manajemen Strategis: Formulasi, Implementasi dan pengendalian. Jakarta: Salemba Empat, 2008. Print.

Porter, M.E. Competitive Advantage Creating and Sustaining Superior Performance. New York: The Free Press, 1985. Print.

Sinambela, P.L. Reformasi Pelayanan Publik Teori, Kebijakan, dan Implementasi. Jakarta: PT. Bumi Aksara, 2010. Print.

Tjiptono, Fandy. Service Management: Mewujudkan Layanan Prima Edisi II.Yogyakarta: Andi, 2012. Print.

Ward dan Peppard. Strategic Planning for Information System 3nd ed. England: John Wiley \& Sons, 2002. Print.

Badan Pusat Statistik Indonesia. Web. https://www.bps.go.id

Direktorat Jenderal Bimbingan Masyarakat Buddha. Web.

http://bimasbuddha.kemenag.go.id

Kementerian Perdagangan Republik Indonesia. Web.

http://www.kemendag.go.id/en

Kementerian Riset, Teknologi, dan Pendidikan Tinggi. Web.

http://ristekdikti.go.id 